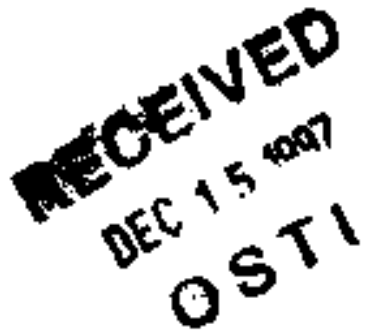

\title{
2020 Vision Project, Fiscal Year 1997 Summary of Student Scenarios
}

K. W. Gordon, A. Muñoz, K. P. Scott, R. Rinne

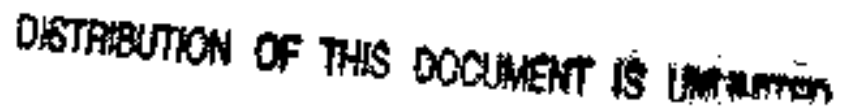

Prepared by

Sandia National Laboratorles

Abuqterqua, Now Mexico 871gs and Livermore, Catfornia 94650

Sandia ta a mulliprogram taboratory operated by Sendie Corporition

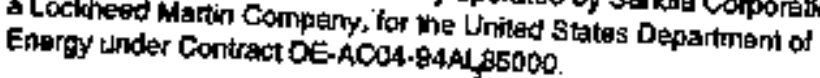

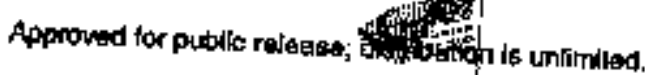

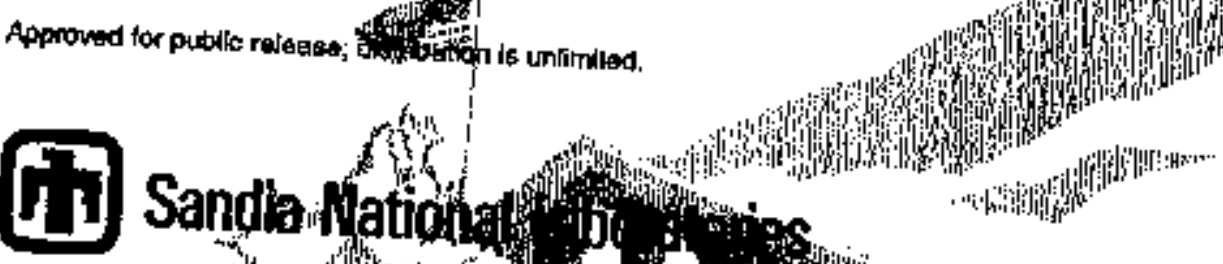


SF29000[8-91\}

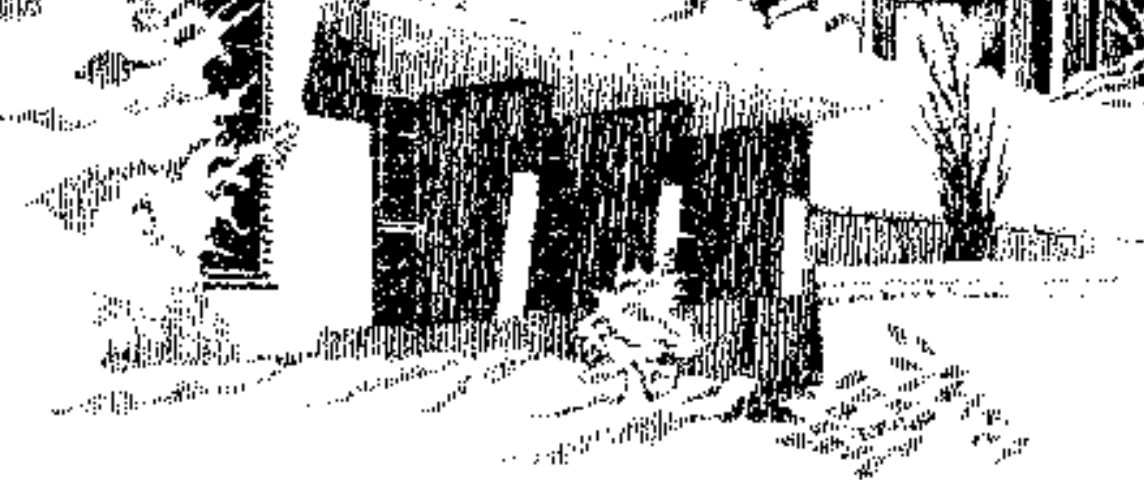


Issued by Sandia National Laboratories, operated for the United States Department of Energy by Sendia Corporation.

NOTICE: This report was prepared as as account of work sponsored by an agency of the United States Government. Neither the United States Govern. ment nor any agency thereof, nor any of their employees, nor any of their contractors, subcontractors, or their employees, makes any warranty, express or implied, or assumes any legal liability or responsibility for the accuracy, completeness, or usefulness of any information, apparatus, product, ar process disclosed, or represents that its use would not infringe privately owned rights. Reference herein to any specific commercial product, process, or service by trade name, trademark, manufaeturer, or otherwise, does not necessarily constitute or imply its endorsement, recommendation. or favoring by the United States Government, any agency thereof, or any of their contractors or subcontractors. The views and opinions expreseed herein do not necessarily state or reflect those of the United States Government, any agency thereof, or any of their contractors.

Printed in the United States of America. This report has been reproduced directly from the best available copy.

Available to DOE and DOE contractors from

Office of Scientific and Technical information

P.O. Box 62

Oak Ridge, TN 37831

Prices available from (615) 576-8401, FTS 626-8401

Available to the public from

National Technical Information Service

U.S. Department of Commerce

5255 Port Royal Rd

Springtield, VA 22161

NTIS price eodes

Printed copy: A03

Microfiche copy: A01 


\section{DISCLAIMER}

Portions of this document may be illegible electronic image products. Images are produced from the best available original document. 
SAND98-8208

Untimited Release

Prirted November 1997

\author{
Distribution \\ Category UC-400
}

\title{
2020 Vision Project, Fiscal Year 1997 \\ Summary of Student Scenarios
}

\author{
Karivine W. Gordon", Angela Munoz ${ }^{*}$, K. P. Scott \\ Science Education and Outreach Department \\ Rob Rinne \\ Advisor for National Security Department \\ Sandia National Laboratories \\ Livermore, CA 94550
}

\begin{abstract}
The Strategic lssues Thinking: 2020 Vision project introduces students and teachers to national security isstues through the techniques of scenario building, and engages them in an interactive process of creating scenarios relevant to the Department of Energy, Defense Programs (DOE/DP). Starting with the world as it is today, teams of students develop a series of scenarios on intermational developments over the next 25 years under various circumstances. This report identifies recurrent themes in the students' scenarios, lists creative ways the students presented their scenarios, compares and contrasts the program's FY97 results with FY'96 results, identifies the benefits of the program, and offers a glimpse of Sandia's future plans for the 2020 Vision project.
\end{abstract}

\footnotetext{
'KARDON Communications, under Contract \#LF-9242

- Stammer Intern from Harvard University
} 


\section{CONTENTS}

Page

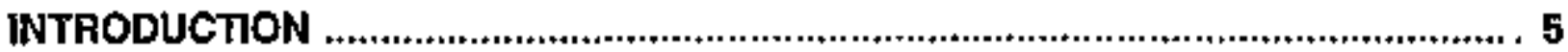

Recurrent Themes

Terrorism and Weapons of Mass Destruction ........................................................................ 7

Regional Concerns ................................................................................................................ 7

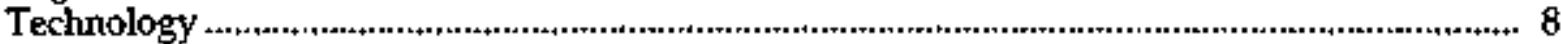

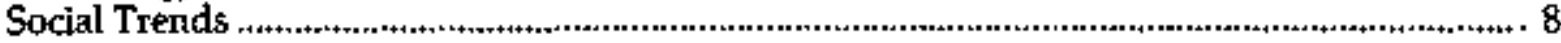

CREATIVE WAYS TO PRESENT SCENARIOS ............................................ 9

COMPARISON AND CONTRAST TO 1996 THEME PAPERS .............................. 9








\section{Vision Project Fiscal Year 1997 \\ Summary of Student Scenarios}

\section{Introduction}

The Strategic Issues Thinking: 2020 Vision project introduces students and teachers to national security issues through the techniques of scenario building, and engages them in an interactive process of creating scenarios relevant to the Department of Energy, Defense Programs (DOE/DP). Starting with the world as it is today, teams of students develop a series of scenarios on international developments over the next 25 years under various circumstances. Students are asked to write a future hustory of U.S. relationships with the world in the context of national security.

The 2020 Vision project in FY97 involved tive teachers from two schools in CaliforniaSan Ramon Valley High School (in Danville) and Elk Grove High School (outside Sacramento). Two methods were used to generate scenarios: 1) development of scenarios based on a single theme and 2) a quadripartite approach using two sets of contrasting conditions to define four potential future directions.

For the first method, teachers chose five themes to guide scenario development: environment, neo-isolationism, religious conflicts, terrortsm, and the economy. The students were divided into teams, and each team member represented a different region of the world. The teams were responsible for coordinating their scenarios given just two rules: 1) the projected events had to be plausible, e.g., they couldn't violate the laws of physics to either create or solve a problem, and 2) the events within a scenario could not be self-contradictory, e.g., there could not be world-wide improved living conditions during a world war.

Sandia adapted the quadripartite approach from scenario planning techniques developed by the Global Business Network. In this method, themes are represented by two sets of opposing relationships, e.g., Cooperative World Government vs. Isolationism and International Control of Weapons of Mass Destruction (WMD) vs. Increasing Concerns (that is, proliferation or cold war) about WMD. These relationships are depicted as two crossing axes, with today at the origin and four possible future directions represented by the resulting quadrants (see Fig. 1). Sandia provided the teachers and students background information on how to use the technique, sample scentarios, and four pairs of axes from which to choose for their ciass scenarios. After selecting a set of axes, the teachers divided the students into teams, each responsible for writing a scenario for one of the quadrants. Again, each team member represented a different region of the world. 


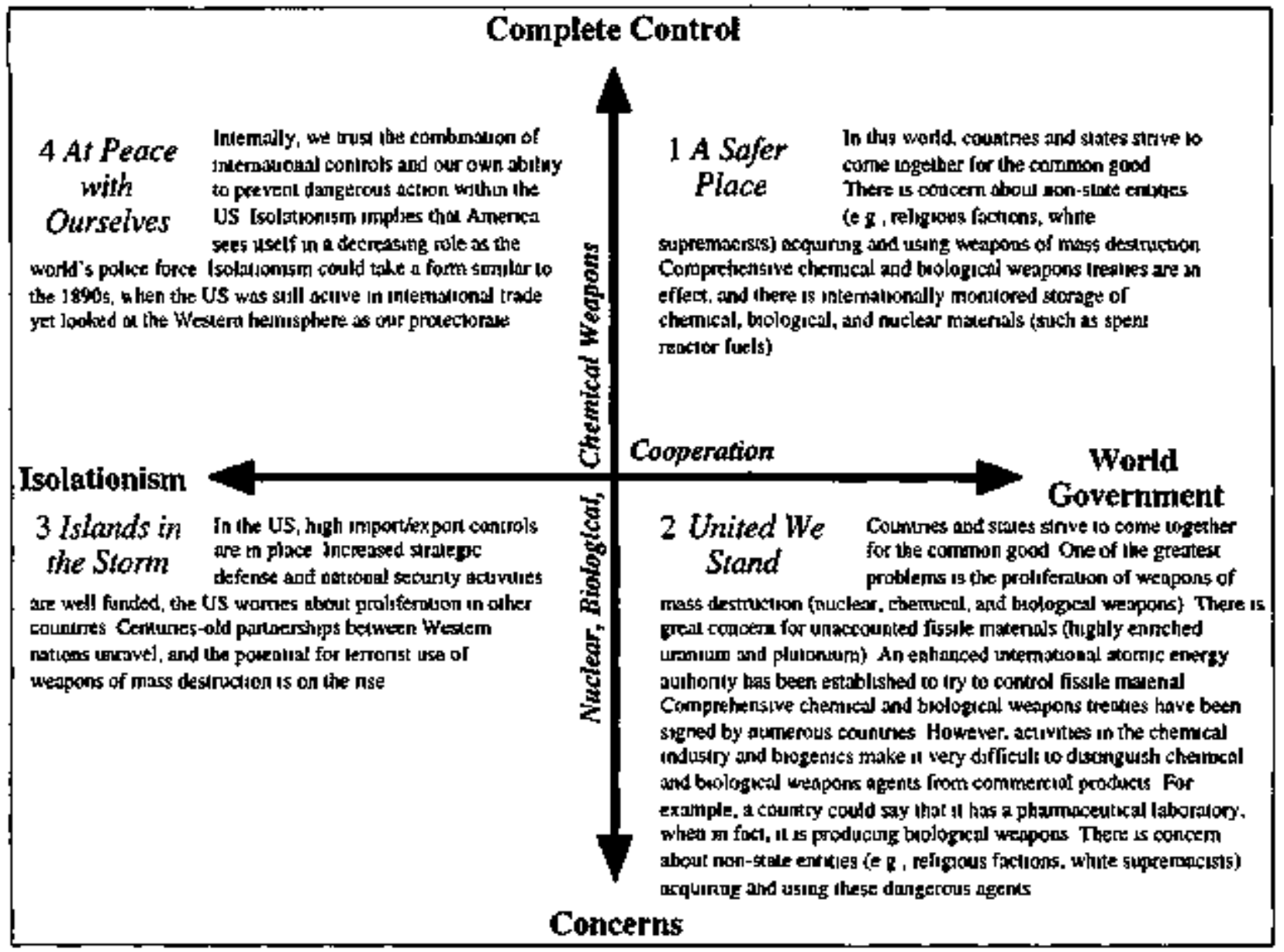

Figure 1. An example of axes tised for the 2020 Vrsion scentrio buildtitg exercise-

Whichever method they used, the students wrote scenario papers for the years 2000,2010 , and 2020. This report describes recurrent themes, lists creative ways the students presented their scenarios, compares and contrasts FY97 results with FY96 results, identifies rewards for students and teachers, and offers a glimpse of Sandia's future plans for the program.

\section{Recurrent Themes}

Several pressing issues repeatedly appeared in many of the scenarios. In general, the students were most concerned about terrorism, higher crime rates, nuclear weapons, AIDS and other deadly diseases, drugs, bankruptcy of social security, and the cloning of humans. Many of them also were concerned about certain "high risk" geographical regions, such as China and the Middle East. Generally, they were least concened about national defense and energy supplies-not because these issues are not important to them but because they largely assume that the US. will easily be able to defend its sovereignty and that alternative sources of energy will be developed in the next 25 years. Regions of the world that caused the least concern were Canada (which was largely ignored) and Europe. The students varied widely in their responses to some issues, such as the role of technology in the future and the direction of education in this 
country; these issues were either a source of great concern or a source of positive influence on society,

\section{Terrorism and Weapons of Mass Destruction}

Terrorism evoked the strongest responses ftom the students. They almost universally assume the future will be full of terrorist acts, primarily initiated by Middle Eastern countries (although they also a potential increase in domestic terrorism). Many of the scenarios envisioned bombs-especially nuclear bombs-being dropped on New York City (notably not on other major US. cities, such as Los Angeles, San Francisco, or Washington DC). However, attitudes toward terrotism ranged from fear to desensitized acceptarke. On the one hand, in many scenarios, there was a huge underlying fear and perhaps a feeling of hopelessness about terrorism and violence, a hopelessness that also is evident in the scenatios that mentioned high crime levels in the future. On the other hand, some scenarios displayed a sort of blasé view of the issue. Writing in the first person about a college student on an airline flight in the year 2000 , one team wrote, "Ryan mused over the idea that even he wasn't surprised anymore by terrorism...terrorism was not uncommon in the U.S. and he didn't even think twice about it." Many of the students also saw terrorism changing with the tides of technology, to include nuclear, biological, chemical, and even computer terrorism ("cyber-terrorists").

The students generally felt that besides their use in terrorist activities, WMD will likely be used in conflints between nations. For example, more than one team envisioned a nuclear exchange between India and Pakistan. Others saw Iraq using chemical weapons against the Kurds in northern Iraq. Many students also were concerned about what Russia is doing with its nuclear stockpile in the context of its failing economy. Although they mostly envisioned Russia's return to communism, they were not so concerned about a new "cold war"; rather, they were concerned about Russia selting its nuclear weapons to terrorists and "togue countries." One team described Russian nuclear weapons being used in a conflict between Iran and Irag.

\section{Regional Concerns}

The two regions of the world that caused the most concern were China and the Middle East, with concerns about China being centered on Hong Kong. Most students envisioned that the hand-over of Hong Kong to China, which began peaceably in the scenarios, would tum sour, as China would try to impose communism on the territory. Concerns even went as far as to describe an expansionist Chinese government that would take over not only Hong Kong, but also Taiwan, starting a domino effect in Southeast Asia, much like the Soviet bloc countries after World War I. In general, the students saw China's role and power in the world increasing in the first part of the next century.

Concerns about the Middle East centered on oil and the acquisition (and sometimes use) of nuclear weapons by "rogue" countries such as Iraq. Several scenarios involve a military dictator who takes over the entire Middle East and its oil. However, the students sometimes 
found it easier to Iump all the Middle Eastern countries into one entity than to consider the differences among them.

Other regions that consistently raised concerns were Africa and South America Most of the students saw drugs as the biggest influence on the economies and governments of Latin American countries, which limited their views of other issues that might influence Latin America in the next 25 years. As sometimes occurred in their treatment of the Middle East, they also latgely lumped all of the Latin American countries together and failed to consider the differences among them Most of the students writing about Africa described continuing civil and ethric wars, political and social chaos, and ever more deadly diseases.

\section{Technology}

Most of the students saw the world moving further into the Information Age. The Internet and all the mozal and political issues associated with it were central to many of their scenarios. In general, the students saw an increasing need for computer literacy, as the lntermet will likely become the primary source of news for the world. They also described more (and more need for) government regulation of the Internet. Many of the students have faith that information technology will provide more solutions than problems, but that its dangers lie in computer terrorism and a lack of control of information-particularly information about how to build and detonate a nuclear weapon.

The students' focus on technology also generally assumes the development of new, alternative sources of energy in response to the scarcity of natural resources or the withholding of oil by a Middle Eastern tyrant. Electric or solar-powered cars, as well as oil reserves under the ocean, appeared in many of the scenarios. Although many of the students wrote about these two specific technological issues, few of them addressed other possible technological advances. Some isolated technologies mentioned include voice-activated computers or other appliances, portable virtual reality head gear, and space stations.

\section{Social Trends}

A number of the students mentioned other issues that either do not relate to national security or that may relate only indirectly, but that reflect many of their concerns about social trends. These issues included:

- education-the students were divided on the direction it will take; some saw a large increase in funding and technology in schools, fueled by a greater emphasis on education; some saw schools based on ability tather than age. Others saw the "dumbing" of Antrica-reading skills diminishing and more people blindly accepting the views fed to them by the media;

- the election of a woman president or an African American president (spectfically Colin Powell);

- the national debt continuing to sap the U.S. economy;

- Social Security--5pically viewed that Baby Boomers will cause it to go bankrupt;

- fear of AIDS, Ebola, or a new "mystery disease"; 
- the cloning of people (largely assumed that someone will evertually do it) and its related moral dilemmas.

\section{Creative Ways to Present Scenarios}

The students developed a wide variety of ways to tell their stories. Some of the most engaging scenarios used a character or characters. Yet, some of the report-style papers were well written and consistent, traits that were sometimes missing from the more creative scenarios. The best papers were well-researched, their depth and plausibility enhanced by the use of many secondary sources. In general, these creative approaches made the scenarios interesting to read:

- Newscasts

- 60 Minites-type news show

- Newspaper reports

- New Years' Day review of previous year (or previous decade)

- Teacher-student exchange

- Tìme capsule report

- Science Bowl-type competition ("High School Current Event Challenge")

- Conterence speakers

- One character, progressing in life stages and observing events in that context

- Airplane passenger conversing with seat-mate

- Family discussions

- Personal journal

- Letters between friends

- Two homeless men discussion; each taking a side of an issue. Also, homeless "prophesier"

- Campaign speech

- Interview of President

- Crystal Ball (Madame Gypsy)

- Top 10 list

- Dream sequence

\section{Comparison and Contrast to 1996 Theme Papers}

The students who participated in 2020 Vision in 1997 generated many of the same ideas and concerns as the students who participated in the pilot project in 1996, such as terrorismboth computer terronism and WMD terrorism, Russia reverting to communism (although the students in 1997 showed more concern about Russia selling weapons to terrorists and "rogue countries" than about a new "cold war"), and a military dictator taking over the entire Middle East and control of the world's oil supply.

Some plausibilities that came out of the 1997 papers were different from the 1996 scenarios, such as the Kurds trying to gain independence from Irag, schools based on ability rather than age, disputes over ocean boundaries, and the election of Colin Powell to the Presidency. Some issues arose in 1996, but no one mentioned them in the 1997 scenarios, such 
as Turkey damming the Euphrates and causing even more conflict in the Middle East, global disarmament, and the resurrection of "Star Wars."

Often, the students in 1997 took the themes mentioned by the students in 1996 in a different direction. For example, the students in 1996 mentioned the European Unjon in nearly every scenario; this year, the students barely mentioned it at all, except for when they mistakenly clumped the whole European continent together as one politicat entity. The EU of the 1996 soenarios was also more tightly knit, with the students discussing the dynamics of its economy and suggesting a possible common language and government. In 1997, students only suggested that the EU will have a common currency (which is a stated goal of the EU for 1999).

Table I further compares and contrasts some recurrent themes from both sets of students.

Table 1. Comparison and Contrast of Student Scenarlos-1996 and 1997

\begin{tabular}{|c|c|}
\hline 1996 Theme Papers & 1997 Theme and Axls Papers \\
\hline - Dissolution of NATO or UN & - NATO becomes pro-European peace \\
\hline $\begin{array}{l}\text { European Union is strong, with a common } \\
\text { (official) language, a common currency, and } \\
\text { sometimes even a common governing body }\end{array}$ & - Mention of EU with common currency \\
\hline - War between England and North Ireland & $\begin{array}{l}\text { - Conflict in UK mentioned onIy in theme } \\
\text { papers }\end{array}$ \\
\hline - Damming of Euphrates by Turkey & $\begin{array}{l}\text { - Conflict between Greece and Turkey over } \\
\text { Cyprus }\end{array}$ \\
\hline $\begin{array}{l}\text { Often, Russia reverts to communism; rarely } \\
\text { does it move toward democracy or capitalism }\end{array}$ & $\begin{array}{l}\text { Russia reverts to communism; sometimes } \\
\text { moves toward democracy and free-market } \\
\text { system }\end{array}$ \\
\hline - New Cold War & - Russian "loose nukes" \\
\hline $\begin{array}{l}\text { Russia sells nukes to "rogue courtries" such } \\
\text { as Libya, Iraq, and Syria }\end{array}$ & $\begin{array}{l}\text { - Russia sells nukes to "rogue countries" in } \\
\text { Middle East (such as Iraq) }\end{array}$ \\
\hline $\begin{array}{l}\text { - Some major conflict within the former Soviet } \\
\text { Bloc countries }\end{array}$ & $\begin{array}{l}\text { Former Soviet Bloc countries menthoned only } \\
\text { in the theme papers }\end{array}$ \\
\hline $\begin{array}{l}\text { - Dictator in Middle East rising with nuclear } \\
\text { capabilities }\end{array}$ & - Middle-Eastem tyrant takes over \\
\hline - Resolution of Israel/PLO conflict & - Contliet between Israel and its neighbors \\
\hline $\begin{array}{l}\text { Mexican-US. border patrol stronger in some } \\
\text { cases, yet chastised in one case for being } \\
\text { violent }\end{array}$ & $\begin{array}{l}\text { Border patrol becomes stronger, sometimes } \\
\text { leading to riots in border totwns }\end{array}$ \\
\hline $\begin{array}{l}\text { Japan has a major earthquake, which } \\
\text { devastates the economy; sometimes Japan is } \\
\text { seen as contender for world power }\end{array}$ & $\begin{array}{l}\text { Japan has a major earthquake, which } \\
\text { devastates the economy; sometimes Japan is } \\
\text { seen as contender for world power }\end{array}$ \\
\hline $\begin{array}{l}\text { - China gains power and forms atliance with } \\
\text { Russia; also, China has a massive civil war }\end{array}$ & $\begin{array}{l}\text { - China becomes a dominant world power; takes } \\
\text { over not only Hong Kong, but Taiwan and } \\
\text { sometimes other Southeast Asian countries }\end{array}$ \\
\hline - Virtually no mention of Africa & $\begin{array}{l}\text { - Africa is a source of deadly diseases, chaos, } \\
\text { and ethric and civil war }\end{array}$ \\
\hline
\end{tabular}


Table 1. Comparison and Contrast of Student Scenarios-1996 and 1997 (concluded)

\begin{tabular}{|c|c|}
\hline 1996 Theme Papers & 1997 Theme and Axis Papers \\
\hline - Virtually no mention of South America & $\begin{array}{l}\text { - Biggest problem in South America is drugs } \\
\text { (and their corruption of governments) }\end{array}$ \\
\hline - Quebec secedes from Canada & - Virtually no mention of Carada \\
\hline - Global disarmament a common theme & $\begin{array}{l}\text { - Proliferation and terrorism common, but } \\
\text { virtually no mention of global disarnament }\end{array}$ \\
\hline - Examples of nuclear terrorism & $\begin{array}{l}\text { - Rampart nuciear terrorism, including the } \\
\text { invention of the "pocket nuke" }\end{array}$ \\
\hline $\begin{array}{l}\text { - In isolation, U.S. focuses more on donestic } \\
\text { problems }\end{array}$ & $\begin{array}{l}\text { - Some students viewed isolationism as leading } \\
\text { to U.S. decline; others to U.S. benefit }\end{array}$ \\
\hline $\begin{array}{l}\text { - Resurrection of "Star Wars" (ballistic misssile } \\
\text { defense) }\end{array}$ & - No mertion of Star Wars \\
\hline - First womar elected President (one scenario) & $\begin{array}{l}\text { - In some, Colin Powell or woman elected } \\
\text { President }\end{array}$ \\
\hline - Depression hits the US & - Depression hits the US \\
\hline $\begin{array}{l}\text { - World moves to clean energy source; electric } \\
\text { and solar-powered cars }\end{array}$ & $\begin{array}{l}\text { - Alternative energy sources, as well as electric } \\
\text { and solar automobiles }\end{array}$ \\
\hline $\begin{array}{l}\text { - Information Revolution leads to more jobs in } \\
\text { the United Stafes }\end{array}$ & $\begin{array}{l}\text { Information-based society with increase in } \\
\text { college enrollment, more women in the work } \\
\text { force, and more highly skilled workers }\end{array}$ \\
\hline $\begin{array}{l}\text { - Information Revolution leads to computer } \\
\text { terrorism }\end{array}$ & $\begin{array}{l}\text { - Information Revolution leads to computer } \\
\text { terrorism }\end{array}$ \\
\hline - Improverrent of public education & $\begin{array}{l}\text { - Both sides of spectrum: some saw vast } \\
\text { improvement; others saw dramatic decline }\end{array}$ \\
\hline - Media has negative effect on US. society & - Media has negative effect on U.S. society \\
\hline
\end{tabular}

\section{Rewards}

Scenario building in the high school curriculum is an effective teaching tool. A great strength of the 2020 Vision project in FY97 was the high level of interest it generates among students. They almost universally enjoy the opportunity to think "out-of-the-box" and develop possible answers to questions that really don't have any. The students benefit from being required to use strategic and creative thinking skills-that is, dealing with a problem that has multiple solutions-rather than just critical thinking skilts, which typically reflect learning the one "correct answer." They also benefit from cooperative learning and the use of a variety of research tools, including the Internet. The skills they learn can be applied in many areas of their lives.

For teachers, the 2020 Vision project in FY97 offered an opporturity to expand their curriculum and to use more information technology in the classroom, techrology they normally might not use. It also gave them new ways to interact with their students-e.g., serving as a facilitator rather than a lecturer. The rewards are largely intrinsic-the satisfaction of creating greater value in their students' learning experience. 
Both the students and the teachers gain exposure to Sandiz Nahional Laboratories and the DOE, as well as current thinking among leading scientists. They also gain a better understanding of national security issues. This interaction gives them an additional source of validation for their creative ideas and a sense of contribution to the national security community.

For Sandia, the scenarios offer a generational perspective that is sometimes lacking in the national security community. Many Sandians feel that the scenarios act as a catalyst, helping researchers and managers think about altermative futures.

\section{Future Plans}

The Science Education and Outreach Department will be expanding the $2020 \mathrm{Vision}$ program in the coming school year (1997-98) to include Web-based support. Our eventual goal is to implement the program completely through Web-based applications-induding registration, scheduling, program procedure descriptions and background information, enhanced research tools, communications (chat rooms, e-mail, threaded conversations, document sharing), and other resources. Web pages are under development and will be available for viewing by late September. Mentors will be available through e-mail to answer questions and provide feedback. As a part of this effort, we are improving the documentation so that others can better use the program for project development, planning, and follow-on exercises.

To help the teachers implement the project more consistently in their classrooms, we have developed one method-a hybrid of the theme and axis models-to be used by all classes, and we are providing teachets enhanced training materials.

We also plan to involve more diverse classes-i.e., students from different geographic locations and socioeconomic conditions-in order to broaden the range of viewpoints received. In the 1997-98 school year, at least a dozen teachers from four local schools will participate in the enhanced teacher training, and several DoD schools from overseas have expressed interest in piloting the project through the Web (and attending teacher training at Sandia in Summer 1998). For more information or to offer comments, please contact:

Judie Hurtz, (510) 294-2703, jhurtz@sandia.gov Karen Scott, (510) 294-3760, kpscottosandia.gov 


\section{DISTRIBUTION:}

\begin{tabular}{|c|c|c|c|}
\hline & 1 & $\mathrm{MSO103}$ & Bruce C. Dale, 12100 \\
\hline & 1 & MS 0103 & Ron Detry, 12100 \\
\hline & 1 & $\mathrm{MS} 0127$ & Jennifer R. Bechdel, 4512 \\
\hline & 1 & MS 0127 & John C. Cumnúngs, 4512 \\
\hline * & 1 & MS 0127 & Robert J. Floran, $\mathbf{4 5 1 2}$ \\
\hline & 1 & MS 0127 & Sheryl L. Hingorani, 4512 \\
\hline & 1 & MS 0127 & Glenn W. Kuswa, 4542 \\
\hline & 1 & MS O131 & Daniel J. Alpert, 12120 \\
\hline & 1 & MS 0131 & Shirley Anderson, 12120 \\
\hline & 1 & MS 0131 & Paul Barnett, 12120 \\
\hline & 1 & MS 0131 & Carol Counts, 12120 \\
\hline & 1 & MSOI31 & Craig Meyers, 12120 \\
\hline & 1 & MS 0131 & Lori Parrott, 12120 \\
\hline & 1 & MS0131 & Goidie Piatt, 12120 \\
\hline & 1 & MSO131 & Richard Traeger, 12120 \\
\hline & 1 & MS 0131 & Deborah Wince-Smith, 12120 \\
\hline & 1 & MS 0131 & Gloria Zamora, 12120 \\
\hline & 1 & MS 0149 & Dan Hartley, 4000 \\
\hline & 1 & MS 0159 & Virgil Dugan, 4500 \\
\hline & 1 & MS 0415 & Keith J. Almquist, 5411 \\
\hline & 1 & MS 0415 & Nancy $H$. Ptindle, 5411 \\
\hline - & 1 & MS 0419 & Robert Gough, 5336 \\
\hline & $\frac{1}{1}$ & $\begin{array}{l}\text { MSO421 } \\
\text { MS } 0425\end{array}$ & Curtis Hines, 5401 \\
\hline & 1 & MS 0445 & $\begin{array}{l}\text { Richard R. Preston, } 5415 \\
\text { Randy Harrison, } 2166\end{array}$ \\
\hline - & 1 & MS 0458 & $\begin{array}{l}\text { Randy Harrison, } 2166 \\
\text { Laura Gill jom, } 5133\end{array}$ \\
\hline & 1 & MS 0463 & $\begin{array}{l}\text { Laura Gill jom, } 5133 \\
\text { William M. Knauf, } 5001\end{array}$ \\
\hline & 1 & MS 0465 & $\begin{array}{l}\text { William M. Knauf, } 5001 \\
\text { James F. Ney, } 5100\end{array}$ \\
\hline & 1 & MS D467 & $\begin{array}{l}\text { James F+ Ney, } 5100 \\
\text { Clyde Layne, } 4102\end{array}$ \\
\hline & 1 & MS0469 & Keith Johnstone, 5006 \\
\hline & 1 & MS 0469 & John M. Taylor, 5336 \\
\hline & 1 & MS 0472 & Jetry Allen, 5131 \\
\hline & 1 & MS 0472 & A. Kay Hays, 5136 \\
\hline & 1 & MS 0482 & Andrew Cox, 5161 \\
\hline & 1 & MS 0660 & John Whitley, 4622 \\
\hline & 1 & MS 0702 & Dan Arvizu, 6200 \\
\hline & 1 & MS 0736 & Nestor Ortiz 6400 \\
\hline & 1 & MS 0860 & Chuck Carson, 9122 \\
\hline & 1 & MS0880 & Nicholas Hawkins, 4411 \\
\hline & 1 & MS 0953 & William Alzheimer, 2900 \\
\hline & 1 & MS 0985 & Michae] Callahan, 5202 \\
\hline & 1 & MS 1002 & Patrick Eicker, 9600 \\
\hline & 1 & MS 1068 & Gary Beeler, 14000 \\
\hline & 1 & MS 1071 & Ted Dellin, 22033 \\
\hline & 1 & MS 1143 & Dori Ellis, 14600 \\
\hline & 1 & MS 1378 & Olin H. Bray, 4524 \\
\hline - & 1 & MS 1378 & Dennis Engi, 4504 \\
\hline & 1 & MS 1378 & Shanna Narath, 4524 \\
\hline & 1 & MS 1393 & Chuck Oien, 5200 \\
\hline - & 1 & MS 1393 & Carolyn Pura, 5200 \\
\hline & 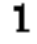 & MS 1415 & Wil Gauster, 1112 \\
\hline
\end{tabular}




\section{Dlstribution (continued)}

\begin{tabular}{|c|c|c|}
\hline 1 & MS 9001 & Thomas O. Hunter, 8000 \\
\hline 1 & MS 9002 & Pat Smith, 8500 \\
\hline 1 & MS 9003 & Dona Crawford, 8900 \\
\hline 1 & MS 9004 & Mim John, 8100 \\
\hline 1 & MS9005 & Jim Wright, 2200 \\
\hline 1 & MS 9006 & Don Bohrer, 2203 \\
\hline 1 & MS 9006 & Dave Havlik, 5204 \\
\hline 1 & MS 9007 & Art Pontaut, 8801 \\
\hline 1 & MS 9007 & Rick Wayne, 8400 \\
\hline 1 & MS 9011 & Peter Wyckoff, 8950 \\
\hline 1 & MS 9012 & Jim Costa, 8920 \\
\hline 1 & MS 9013 & Russ Miller, 2266 \\
\hline 1 & MS 9014 & A] Baker, 5209 \\
\hline 1 & MS 9014 & Thomas Harrison, 2271 \\
\hline 1 & MS 9014 & Jim Hogan, 2271 \\
\hline 1 & MS 9014 & Hank Irwin, 2221 \\
\hline 1 & MS 9014 & Robert Kinzel, 2221 \\
\hline 1 & MS 9014 & Ed Talbot, 2226 \\
\hline 1 & MS 9014 & Bill Wilson, 2221 \\
\hline 1 & MS 9015 & L. K. Groves, 2221 \\
\hline 1 & MS 9017 & Randy Christman, 8501 \\
\hline 1 & MS 9017 & Denise Koker, 8209 \\
\hline 1 & MS 9021 & Judd Hollister, 8815 \\
\hline 1 & MS 9033 & Corey Knapp, 2262 \\
\hline $\mathbf{I}$ & MS 9035 & Kevin Carbiener, 2265 \\
\hline I & MS9035 & Robert Monson, 2265 \\
\hline ! & MS 9036 & Doug Herson, 2254 \\
\hline 1 & MS 9037 & Ron Stoltz, 12120 \\
\hline 1 & MS9041 & Steve Binkley, 8000 \\
\hline 1 & MS9042 & Dan Dawson, 8746 \\
\hline 1 & MS9052 & Don Hardesty 8361 \\
\hline 1 & MS 9052 & Larry Baxter, 8361 \\
\hline 1 & MS 9052 & Steve Buckley, 8361 \\
\hline 1 & MS9053 & Bob Gallagher, 8366 \\
\hline 1 & MS9053 & Bob Green, 8362 \\
\hline 1 & MS 9053 & Fay Keller, 8362 \\
\hline 1 & MS 9054 & Bill McLean, 8300 \\
\hline 1 & MS 9056 & John Vitko, 8102 \\
\hline 1 & MS 9101 & Bill Peila, 8411 \\
\hline 1 & MS 9103 & Greg Thomas, 8111 \\
\hline 1 & MS 9104 & Will Bolton, 8120 \\
\hline 1 & MS 9105 & Howard Hirano, 8412 \\
\hline 1 & MS 9105 & Jane Ann Lamph, 8412 \\
\hline 1 & MS 9108 & Ed Cull, 8414 \\
\hline 1 & MS 9108 & Raymond Ng, 8414 \\
\hline $\mathbf{1}$ & MS 9116 & Craig Smith, 8534 \\
\hline 1 & MS 9141 & Paul Brewer, 8600 \\
\hline 1 & MS 9141 & Len Hiles, 8800 \\
\hline 1 & MS9141 & Robert Rinne, 8104 \\
\hline 1 & MS 9161 & Walter Bauer, 8358 \\
\hline 1 & MS 9201 & Marty Abrams, 8114 \\
\hline
\end{tabular}




\section{Distribution (continued)}

MS 9403

MS 9405

MS 9405

MS 9405

MS 9420

MS 9430

MS 9731

MS 9904

MS 9904

M5 9904

M5 9018

MS 0899

MS 9021

MS 9021
Rob Allen, $\mathbf{8 1 1 2}$

Larry Brandt, 8112

Troy Delano, 8114

Donna Edwards, 8112

Pat Falcone, 8114

Vipin Gupta, 8112

Susanna Gordon, 8112

John Hirton, 8114

Wen Hsu, 8112

Michael Johnson, 8114

Curt Nilsen, 8114

Gary Richter, 8114

Charlton Shen, 8112

Richard Wheeler, 8112

Rene Bierbaum, 8116

Charles DeCarli, 8116

Judy McEwan, 8116

Debbie Post, 8116

Juan Meza, 8117

Len Napolitano, 8117

Mark Perra, 8711

Bill Even, 8713

Jim Wang, 8713

Mike Dyer, 8700

Jim Lathrop, 8743

Duane Lindner, 5404

Al West, $\mathbf{8 2 0 0}$

Anton West, 8240

Dennis Nelson, 8812

Karinne Gordon, 8818

Judie Hurtz, 8818

Karen Scott, 8818

CentralTechniçal Files, 8940-2

Technical Library, 4916

Technical Communications Dept., 8815 for DOE/OSTI

Technical Communications Dept., 8815/Technical Library, MS 0899, 4916 
This page intentionally left blank 